\title{
The Role of the Public Prosecutor in Korea: Is He Half-Judge?
}

\author{
Heekyoon Kim*
}

\begin{abstract}
Worthy of note is that the Korean prosecutors actually interrogated the suspects and the prospective witnesses like the French examining magistrate did. Furthermore, they reported the result to the trial courts, and the courts' decisions were widely based on those reports, as a practical matter. We might be able to say that, in that sense, the Korean prosecutors might be considered half-judges. It was sometimes argued that the Korean prosecutors had been nearly promoted to the group of examining magistrate. All that happened was due to the practice that gives relatively high credit to the protocols of the prosecutors.

Now, the Judiciary Reform in Korea begins to consider the prosecutor just as the commander of the investigation and, at the same time, as the proper party in an open trial. It means that the true adversarial system will be introduced and tried here. I am curious to see how the prosecutorial office will react in this paradigm shift. Visibly, the prosecutors are well prepared for the change and it would be also a good thing for the prosecutor himself to stop working as the judge.
\end{abstract}

*The author is an Assistant Professor of Law, Sungshin Women's University, Korea (e-mail: kyoon@sungshin.ac.kr). He received an LL.B. in 1990 from Seoul National University College of Law; an LL.M. in 2002 and a J.S.D. in 2005 from the Indiana University School of Law at Bloomington, U.S.A. 


\section{Introduction}

The following comment, though far from a result of an empirical survey, shows what ordinary people think what legal professionals are like:

$[\mathrm{N}]$ eutrality had been associated primarily with judges and was thought to describe a trait that distinguishes judges from lawyers. The emerging notion of prosecutorial neutrality recalls the traditional conception of prosecutors as "quasi-judicial" officers. It emphasizes the distinction between prosecutors and lawyers for private parties. ${ }^{1)}$

To summarize roughly, the public does not care much about how the lawyers act in public or out of sight because they are believed to be no more than the surrogates for private parties. However, concerning the behaviors of the quasi-judicial officers or judicial officers, the tax payers expect much: they hope that a certain judge would be neutral and that a prosecutor would be nearly as neutral as a judge.

The Korean prosecutors have recently been the key target of the governmentoriented reform project. ${ }^{2)}$ They have been considered one of the most powerful legal professions in Korea for more than a half century after the emancipation from the Japanese colonization. Reformers are complaining that the Korean prosecutors did not seem to be sufficiently neutral. They "have been criticized for their reluctance to investigate corruption cases involving powerful politicians or high-ranking government officials, or for their politically biased investigation of the cases." ${ }^{\text {"3) }}$ One notable commentator has gone even further. According to his description of the Korean prosecutors in general, as far as one is concerned about the prosecutorial office, the Korean society needs a revolutionary change rather than a simple reformation or remodeling. Here we follow his grotesque description of the Korean prosecutors, even though it is rather argumentative than scientific:

1) Bruce A. Green, Prosecutorial Neutraility, 204 WIS. L. REV. 837, 839-40 (2004).

2) The Korean judicial reform aimed to make the trial court the center for a fact-finding process. To do that, it was absolutely necessary to invite as much evidence as possible to be examined in an open court. Thus, the reforming effort was concentrated on redefining the admissibility of the transcription of a suspect's statement as prepared by a public prosecutor according to the stricter hearsay rule.

3) Kuk Cho, The Unfinished “Criminal Procedure Revolution” of Post-Democratization South Korea, 30 DENV. J. INT’L. \& POL’Y 377, 386 (2002). 
In the past, [Korean prosecutors] have abused their mighty public power to please power-holders. For example, the prosecutors have indicated many political dissenters on charges of violating the National Security Law, which is designed to protect South Korea from the threat of North Korea .... The longstanding practice of misusing prosecutorial power to suppress political opposition has helped give Korean prosecutors a bad name. ${ }^{4}$

I personally do not intend to defend the Korean prosecutorial office. Moreover, if Korean people do not trust the prosecutor's office, I believe that they might have sufficient reasons to feel that way. However, critical views do not automatically guarantee a new set of measures to enhance the neutrality of the Korean prosecutors. Our primary interest is not in adding skeptical comments on the existing system, but to give a clear idea of who is a Korean prosecutor and of what he is supposed to do according to the Korean Constitution and the Korean Criminal Procedure Code (hereinafter "CPC"). ${ }^{5)}$ After a clear picture has been given, we can analyze why the prosecutorial work has been wrongfully distorted. Then, we may be able to find a solution for democratizing the prosecutorial office. In that sense, any comments and recommendations for creating a more democratic or neutral prosecutorial office should be based on the understanding of how the office presently works in Korea.

A second chapter will be focused on the regulatory scheme of Korea with regard to the public prosecutor's judicial powers. While carefully examining which powers are given to the prosecutors, we can possibly think about another interesting project - that is, to compare the Korean prosecutor with any functionaries the Westerners are familiar with. The Korean prosecutor is very similar to the English Justice of the Peace $^{6}$ ) (hereinafter "JP"), but there is a substantial difference between them. The Korean prosecutor is also basically doing the same things as the French procureur de la République [public prosecutor], but these two are not of the same class. Another interesting similarity is between the Korean prosecutor and the so-called examining magistrate. ${ }^{7}$ All these comparisons will be discussed in the third chapter. In the

4) Jaewon Kim, The Ideal and the Reality of the Korean Legal Profession, 2 Asian-PAC. L. \& PoL'Y J. 45, 55-7 (2001).

5) See generally the Korean Criminal Procedure Code [hyeongsa sosongbeop] (Law No. 341, Sept. 23, 1954, last revised June 1, 2007 as Law No. 8496).

6) See generally John H. Langbein, Prosecuting Crime in the Renaissance, at Part I (1974).

7) For the definition of the magistrates in France, see e.g., Gaston Stefani, Procedure Penale 37 (17d ed. 2001). 
fourth chapter, I would like to return to the very real issue of why the Korean prosecutor has come to be the main target in the Korean judiciary reform project. I would also question whether or not it is really reasonable to attack the reliability of a document made by the Korean prosecutor. That issue will be fully discussed just prior to the final comment on the on-going judiciary reform in Korea.

\section{The Role of a Korean Prosecutor}

As is generally acknowledged in Korea, the prosecutor governs the entire criminal procedure. He has the right to open an investigation and to stop it. $\mathrm{He}$ "is in charge of criminal investigation," ${ }^{\text {"8) }}$ and the police are under his command. ${ }^{9)}$ Save some misdemeanors which are punishable by fines, ${ }^{10)}$ almost every crime has to be reported to the prosecutorial office. ${ }^{11)}$ The police and private parties are prohibited to release any suspects without the prosecutor's permission after the criminal accident has been recorded in the police file. ${ }^{12)}$ There is not any private prosecution ${ }^{13)}$ or any grand jury indictment. ${ }^{14)}$ Only the prosecutors have the right to inform the crimes to the trial court, whether it is a bench or jury trial. ${ }^{15)}$ Thus, in everyday practice, the

8) Jaesang Lee, New Criminal Procedure Code [Shinhyeongsa sosongbeop 97 (2007); See also CPC, supra note 5, at arts. 196-98.

9) See id. The French Criminal Procedure Code also states that the prosecutor "directs the activity of the judicial police officers and agents within the area of jurisdiction of his court," C. PR. PEN. art. 41.

10) See, e.g., "some minor offenses, which are punishable by fines of not more than 200,000 won (currently equivalent to about U.S. \$ 170) or detention for less than thirty days, may be brought by the chief of police before the court without a formal indictment," Kuk Cho, supra note 3, at 381.

11) See, e.g., "[W]hen a judicial police officer receives a complaint or accusation, he shall report the matter pertaining thereto promptly, to a public prosecutor," CPC, supra note 5, at art. 238.

12) See "Only the prosecutor has the right to terminate any investigation," JAESANG LEE, supra note 8, at 97; See generally CPC, supra note 5, at arts. 246-7.

13) See id. On the other hand, the French Criminal Procedure Code opens the possibility of civil action by stating that " $[\mathrm{C}]$ ivil action aimed at the reparation of the damage suffered because of a felony, a misdemeanour or a petty offence is open to all those who have personally suffered damage directly caused by the offence," C. PR. PEN. art. 2.

14) There is no provision regarding the grand jury indictment even in the recently promulgated Law on the Lay Participation in the Criminal Justice [Kukmineui Hyeongsajaipan Chamyeoe Gwanhan Beoplyul] (Law No. 8495, promulgated June 1, 2007).

15) With the promulgation of the Law on the Lay Participation in the Criminal Justice(hereinafter "LPCJ"), the 
prosecutor is in the very center of criminal procedure.

He not only handles almost every crime that occurs in Korea, but the prosecutor also has the power to decide how to close criminal cases. If he closes a case not involved with any functionaries' misuse of administrative power, ${ }^{16)}$ the only remedy available for the criminal victims or harmed parties was the constitutional challenge. That sort of challenge had been so rapidly accumulated in the dockets of the Constitutional Tribunal that it was not considered an effective way to control the prosecutor's power. As a matter of fact, Korean "prosecutors retain full authority for both investigation and prosecution in Korea under a principle of monopoly."17)

The case in Korea is allegedly this:

The prosecutor is supposed to be involved in any stages from the primary investigation to the execution of the court's decision and can be defined as a governmental agent playing the active role in accomplishing the criminal justice. In other words, he directs and commands the police officers in investigation, solely decides whether or not to indict suspects, petitions, in an open court, strict application of a certain criminal act for those suspects, and finally, after the trial, manages the execution of sentences. ${ }^{18)}$

If we say that the prosecutors in general have enormous power in the criminal justice system, it is also true in Korea.

However, we need to think about and clarify one thing in order to correctly understand the role of a prosecutor in Korea - that is, whether or not he has the right to make a dossier, transcript, protocol or whatever, and certify it to the trial court. If the answer is in the positive, the Korean prosecutor is not basically different from the examining magistrate proprement dit in France, and our criminal procedure code can be said to be close to the Continental Inquisitorial system. If we say that the Korean prosecutor is just in charge of the investigation and, with the results of that investigation, simply represents the government in the trial, our system will be

defendant is given the right to a jury trial. See generally LPCJ at arts. 8, 13.

16) Before the recent revision, any challenge to the prosecutor's exclusive right of prosecution was possible in several crimes such as wrongful excercise of authority. However, it is now open to every crime. See generally CPC, supra note 5, at art. 260.

17) Kuk Cho, supra note 3, at 381.

18) JAESANG LEE, supra note 8 , at 81. 
described as adversarial.

The factor that distinguishes the inquisitorial system from the adversarial one is closely related to the prosecutor's pretrial examination. The United States' Supreme Court accordingly pointed out that:

English common law has long differed from continental civil law in regard to the manner in which witnesses give testimony in criminal trials. The commonlaw tradition is one of live testimony in court subject to adversarial testing, while the civil law condones examination in private by judicial officers. ${ }^{19)}$

The point is that, in the Continental Inquisitions process, several judicial officers may be involved with the fact-finding process and even certify some facts as evidence to the trial court. The Inquisition system is that "of criminal procedure in which the magistrate investigated, principally by interrogation of the accused; reduced the results of his investigation, including the testimony of the accused, to writing; and transmitted this dossier to the final sentencing court for a judgment which was based upon and effectively controlled by the dossier." ${ }^{\text {"20) }}$ To understand the Korean prosecutor, we need to locate prosecutors somewhere in the pretrial process and examine the nature of their job. Generally speaking, prosecutors are as nearly powerful as the juge d'instruction [investigating judge in France]. However, this is not the case in every country. In some countries, prosecutors are doing the jobs that could basically be assigned to the police. ${ }^{21)}$ The task that the Korean prosecutors are in charge of is surely related to connecting the police and the trial court. Not yet clear is whether they are closer to the police or to the court. Visibly, "[a]ll prosecutors' offices in Korea, which are as big and dignified as those of the courts, are located next to court buildings." 22$)$ However, this does not provide the answer to my question. It does not say that prosecutors are equal to judges. The point is whether the prosecutors are capable of replacing the judges as fact/evidence finders in the pretrial examination, and thus of governing the whole criminal procedure beside judges.

19) Crawford v. Washington, 124 S. Ct. 1354, 1359 (2004) (citing 3 W. Blackstone, Commentaries ON THE LAWS OF ENGLAND 373-374 (1768)).

20) John H. LANGBein, supra note 6, at 21.

21) See supra note 6 .

22) Jaewon Kim, supra note 4, at 55. 


\section{Who is the Korean Prosecutor?}

Next, I would like to compare the Korean prosecutor with various types of judicial officers. They have different names and assignments. To compare them with the Korean prosecutor will help develop a clearer idea of who he is.

\section{Korean Prosecutor v. American Prosecutor}

Some argue that "the Korean prosecutors do not view their judicial role or function as subordinate to that of judge"23) and that "this mentality is ... incompatible with the adversarial system, which the Korean legal system presupposes."24) Many commentators actively ascertain that Korea has an adversarial criminal procedure. ${ }^{25}$ ) In some aspects, they have reasonable ground to insist that. ${ }^{26)}$ However, it is a different thing to say that the Korean prosecutors are supposed to do the same work as the American counterpart, just because Korea and the United States are both employing the so-called adversarial criminal system. In reality, the two countries' prosecutors are not of the same kind. The American prosecutors seem rather bizarre in terms of police-prosecutor relations, and this is evident from simply comparing them with the French/Korean colleagues. The following description is about the difference between two groups of prosecutors face to face over the Atlantic:

The French prosecutor must be kept informed, at an early stage, of the existence and progress of the investigation. This permits the prosecutor to have more input into the direction and methods of investigation. If the offense is one that will probably not be prosecuted, the police may avoid wasting time and unnecessarily bothering the suspect, his or her associates, and witnesses. If the police are using questionable investigatory methods, the prosecutor may be able to intervene in time to protect both the rights of citizens and the admissibility of the evidence. ${ }^{27)}$ In contrast to this "integrated" model, the

23) Id.

24) $I d$.

25) See, e.g., Yongseok Cha \& Yongseong Choi, Criminal Procedure Code [Shinhyeongsa sosongbeop] 62 (2d ed. 2004).

26) About the typical features showing that the Korean criminal procedure embodies the adversarial system, see generally JAESANG LEE, supra note 8, at 42-44. 
police and prosecutorial functions in the United States seem to reflect a strict "division of labor" theory. American prosecutors are rarely involved in prearrest investigation decisions or in the arrest decision itself. ${ }^{28)}$

If we are able to designate the French criminal procedure model as an "integrated" one, Korea has the same system as France. To understand the prosecutors role in Korea, all we have to do is just replace the word "French" with "Korean" in the above sentences. The Korean prosecutor works with the police under the "integrated" model. There is no theory of "divison of labor," as far as we are concerned with pretrial activity. However, a difference from the French case is that there is no direct path from the police station to the judge in Korea. ${ }^{29)}$ Save some minor offenses, ${ }^{30)}$ all the results of criminal investigations are to be gathered in the prosecutorial office. There it is decided whether or not to take the case to the court. In that sense, Korea has a far more integrated model than France.

The situation being so, the fact that two nations, such as Korea and the U.S., both basically have an adversarial criminal system does not say much about the similarity of the prosecutors' work in the two nations. As is generally taught in the Judicial Research Training Institute, ${ }^{31)}$ from the comparative point of view, the Korean prosecutor is rather an adherent to the French procureur de la République.

Prosecutors are historical products of the Continental criminal procedure governed by the Nation. The position of the prosecutor is very close to the socalled procureur $d u$ roi in the fourteenth century. Nonetheless the procureur $d u$ roi at that time was nothing more than an officer who was in charge of governmental lawsuits for procuring fines and forfeits. In 1808, the Napoleonean Criminal Instruction Code [le Code d'Instruction Criminelle] changed the name to the procureur de la république, and this was imported

27) In Korea, this sort of prosecutorial power is called the right to inspect the detention place. See CPC, supra note 5, at art. 198-2.

28) Richard S. Frase, Comparative Criminal Justice as a Guide to American Law Reform: How Do the French Do It, How Can We Find Out, and Why Should We Care?, 78 CAL. L. Rev. 539, $557-58$ (1990).

29) See generally Mary M. Preumont, La Procedure de Comparution Immediate en Matiere Penale 33 (Bruxelles, 2001).

30) See supra note 10.

31) See generally Judicial Research Training Institute, Prosecutorial Practice I [Gumchal Silmu I] 3-5 (JRTI, 2005). 
through Germany and Japan to our country. ${ }^{32)}$

\section{Korean Prosecutor v. French Prosecutor/French Examining Magistrate}

To understand the nature of the French prosecutorial work, we have to juxtapose the prosecutor with the examining magistrate, and "[o]ne of the most distinctive institutions of French criminal procedure is that of the examining magistrate." 33 ) Without saying anything about small crimes and infractions, every serious crime should not directly reach the trial court. Two sorts of magistrates are supposed to handle the cases before trial.

Ces magistrats dont la situation est différente se différentient surtout par leurs fonctions. Le juge qui n'a pas le droit de poursuivre, ne peut se saisir luimême d'une affaire pénale. De son côté, le [procureur de la République] qui a seulement le droit de poursuivre, n'a pas en principe le pouvoir d'effectuer des actes d'instruction. [These magistrates whose positions are different are supposed to do the different works. The investigating judge, who does not have the right to accuse, cannot take charge of any criminal case for himself. On the other hand, the public prosecutor who has exclusively the right to accuse cannot effectuate the acts of pretrial examination]. ${ }^{34)}$

The examinging magistrate, which is called juge d'instruction in France, has been invented "for more direct and efficient judicial control over both police and prosecutorial discretion at the investigatory and charging stages" ${ }^{35)}$ and it "combines the functions of police, prosecutor, investigating grand jury." ${ }^{36)}$ Certainly, "the French today make relatively little use of this procedure [of the examining magistrate]." ${ }^{37)}$ Nevertheless, the basic structure of pretrial investigation remains undisturbed. There is on the one hand the procureur de la république who "receives complaints and denunciations and decides how to deal with them," ${ }^{38)}$ and "institutes or causes to be

32) JAESANG LEE, supra note 8 , at 87.

33) Richard S. Frase, supra note 27, at 666.

34) GASTON StEFAni, supra note 7, at 37.

35) Richard S. Frase, supra note 27, at 666-67.

36) Id.

37) $I d$. 
taken any step necessary for the discovery and prosecutions of violations of criminal law. ${ }^{39)}$ Judicial police operations are carried out under the direction of the district prosecutor. $^{40)}$ On the other hand, there is an investigating judge who has the right to interrogation. $^{41)}$

The same is basically true in Korea. There is a prosecutor who commands and directs the investigation. Furthermore, as is true in France, his investigating power is limited in certain aspects. He has to have the warrant of arrest or detention from the district judge who is assigned to issue the warrants for some periods. For officially gathering evidence and preserving it, he has to address the district judge. ${ }^{42)}$ As is true for interrogating witnesses before trial, the article states that:

In case persons who are deemed likely to know facts that are indispensable for the investigation of crimes refuse to appear or make statements under the preceding Article, public prosecutors may request judges to interrogate them as witnesses only before the date of the first public trial day. ${ }^{43)}$

All the proceedings, which include "attachment, investigation, verification, examination of witness, or expert opinion," ${ }^{44)}$ are called pretrial examination or simply instruction in French.

Les actes d'instruction. Ce sont les actes qui ont pour but la recherche et la réunion des preuves de l'infraction, qu'ils soient accomplis par les juridictions

38) C. PR. PEN. art. 40.

39) C. PR. PEN. art. 41.

40) C. PR. PEN. art. 12.

41) For the explication of the interrogation, l'interrogatoire in French, see generally GEORGES LEVASSEUR et al., Droit Penal General et Procedure Penale 156 (13d ed. 1999).

42) See CPC, supra note 5, at art. 184, which states that:

"Article 184 (Request and Procedure for Preservation of Evidence)

(1) The public prosecutor, the defendant, a suspect, or his defense counsel may, when there are reasons which may make it difficult to use evidence unless it is preserved in advance, even prior to the date ofr the first public trial, request a judge to effect such measures as attachment, investigation, verification, examination of witness, or expert opinion.

(2) The judge who has received the request prescribed in the preceding paragraph has the same authority as a court or presiding judge has, regarding the dispostion of such request."

43) CPC, supra note 5, at art. 221-2.

44) CPC, supra note 5, at art. 184. 
d'instruction ou même par des officiers de la police judiciaire. [The acts of examination. They are the acts which are means of searching or gathering the evidence of crime, and which are accomplished by the examining magistrate or even by the judicial police officers (hereinafter “OJP”)]. ${ }^{45}$ )

It is very important to figure out whether or not the Korean prosecutor has the right of examination. As is shown above, and as opposed to the examining magistrate, the French prosecutor does not have the right to do that. Neither does the Korean prosecutor. In other words, the initiative in the first step of criminal procedure is not in the hands of prosecutors but in that of the examining magistrate. In a certain sense, prosecutors and district judges or examining magistrates are cooperators, and the basic structure of the pretrial investigation in Korea or France consists of those two top positions. However, the prosecutor cannot be a judge in any event.

The result is that everything said or declared in the presence of the district judge can be qualified as evidence, but what is said to the prosecutor has to pass some sort of evidentiary rule, such as the hearsay rule, in Korea. That is the crucial difference between the roles of prosecutors and district judges. Article 311 makes this point clear by stating that:

Any protocol which contains statements made by the defendant or persons other than the defendant at a preparatory hearing or during public trial, and results of inspection of evidence by courts or judges may be used as evidence. The same shall apply to a protocol prepared pursuant to articles 184 and 2212. ${ }^{46)}$

However, worthy of note is that the Korean prosecutors actually interrogated the suspects and the prospective witnesses like the French examining magistrate did. Furthermore, they reported the result to the trial courts, and the courts' decisions were widely based on those reports, as a practical matter. ${ }^{47)}$ We might be able to say that, in that sense, the Korean prosecutors might be considered half-judges. It was

45) GASTON Stefani, supra note 7, at 172.

46) CPC, supra note 5, at art. 311.

47) See, e.g., "A public prosecutor or judicial police officer shall interrogate as to the necessary matters concerning the facts and conditions of the offense, and shall give the suspect an opportunity to state facts beneficial to himself," CPC, supra note 5, at art. 242. 
sometimes argued that the Korean prosecutors had been nearly promoted to the group of examining magistrate. ${ }^{48)}$

All that happened was due to the practice that gives relatively high credit to the protocols of the prosecutors. As is true in France, CPC in Korea gives full credit to the judges' records. However, the records made by the prosecutors have not been given full credit differently from what the magistrate has written down. ${ }^{49)}$ Thus, the old article 312 said that the transcripts made by the prosecutors could be used as evidence in the trial court, but it specified certain conditions as following:

(1) A protocol which contains a statement of a suspect or of any other person, prepared by a public prosecutor ... may be introduced into evidence, if the genuineness thereof is established by the person making the original statement at a preparatory hearing or during public trial: Provided, that a protocol containing the statement of the defendant who has been a suspect may be introduced into evidence only where the statement was made in specifically trustworthy circumstances, regardless of the statement made at a preparatory hearing or during public trial by the defendant. ${ }^{50)}$

To summarize roughly, "the person making the original statement" has to approve "the genuineness" of the protocol and there should be "specifically trustworthy circumstances" at the moment of making protocol. The CPC's attitude toward the prosecutor's protocol is very similar to that of the French Code regarding the police officer's records. The French Code states that, in principle, the police officers' records or reports "only have the value of simple information," where judicial police officers, judicial police agents or the civil servants and agents entrusted with certain judicial police duties have been granted by a special legislative provision the power to establish misdemeanours by official records or reports, proof of the contrary may only be brought in writing or through witnesses.",52)

The wordings of the Korean and French Codes are not the same, but the fact is

48) President Noh also pointed out the abusive power of Korean prosecutors. See, e.g., Are You Satisfied with Having Insulted the Prosecutorial Office, OHMYNEws (Seoul), Mar. 12, 2003.

49) CPC article 311 does not include the documents prepared by the prosecutors as one of the dossiers which are automatically qualified as evidence. See CPC, supra note 5, at art. 311.

50) CPC, supra note 5, at art. 312(1).

51) C. PR. PEN. art. 430.

52) C. PR. PEN. art. 431 
evident that two acts are not given full credit to the protocols or procès-verbaux made by the police and prosecutors.

\section{Conclusion}

At the very least, one thing is of no doubt: namely that the Korean prosecutor is very different from the American counterpart. At the same time, he is not one of the examining magistrates or investigating judges. Nor is the prosecutor a police officer. No one dares to say that. All that I can say with sufficient conviction is that the Korean prosecutor is located somewhere between the OJPs and the examining magistrate, or the police officer and the district judge, in terms of pretrial examination. This is in fact the point which ignites the judiciary reform in Korea.

\section{Judiciary Reform and the Prosecutorial Office}

\section{Is the Prosecutor Half-Judge?}

A suspect says that he killed a victim, and a public prosecutor writes it down in a document and lets the suspect sign it. It mainly occurred in the investigation office operated by a public prosecutor. When the suspect is accused and summoned in the public court, the judge asks him whether he consented to the introduction of the protocol into evidence. If he says "yes," there is no problem. If he says "no," the foundation process begins. There the old article 312 comes into play and the judge, in most cases, asks the defendant who was a suspect when the transcription was made, whether the signature is his or not. If he says, "yes, that is mine," it is proved that the statement was formally made. ${ }^{53)}$ Then it can be, according to the Supreme Court of Korea (hereinafter "SCK"), legally inferred as fact that the statement was actually made and properly recorded by the prosecutor because the defendant's signature is genuine. ${ }^{54)}$ Traditionally, the SCK ruled likewise for several decades

53) The Korean law has invented a notion that the truthful making of a document consists of formal/truthful making and substantial/truth making. The fact that the signature in a document is truthful only guarantees the formal/truthful making. See generally JAESANG LEE, supra note 8, at 551.

54) See Decision of Sep. 23, 1994, SCK 94 Do 1853. 
when the article 312 was at issue. ${ }^{55}$

How about the second requirement that the statement should be "made in specifically trustworthy circumstances"? The SCK did not care much about it, if only the formal and actual genuineness could be established.

The SCK's ruling on December $16,2004,{ }^{56)}$ has changed nearly everything. It no longer infers the actual genuineness of a transcription from the fact that the accused has signed it. ${ }^{57)}$ Furthermore, it requires that the transcription should have been prepared and made "in specifically trustworthy circumstances" as the article says. What does this change mean? It means that the Korean Judiciary has decided to introduce more developed adversarial settings into the criminal procedure by imposing the stricter hearsay rule and by focusing the adversarial nature partly embodied in the CPC.

From the beginning of 2005, the paradigm shift can be clearly seen in the Korean legal circle. Even the Chief Justice has publicly demanded, "cast away investigating records!"58) The quarrel between the Judiciary and the Department of Justice has made much noise and everybody heard their sayings in newspapers and TV programs. To support the reform project, "[t]he presidential Committee on Judicial Reform was formed on January 18, 2005. This committee [was] focusing on accomplishing an even more democratic, fair, and efficient judiciary with more openness and transparency." ${ }^{59)}$

\section{Donwfall of the Prosecutor}

To have an open and transparent criminal procedure, all the facts should be assessed and questioned in an open court. Regardless of what one said to the police officer at the scene, one has to have the right to deny it in court, and that is important. That issue was handled in the legislation and one legislator concluded that:

In fact, torture in the criminal process in Korea is well-known. The point is how to stop it. I believe that, first of all, we have to exclude the transcripts and

55) See, e.g., Decision of Jun. 26, 1984, SCK 84 Do 748.

56) Decision of Dec. 16, 2004, SCK 2002 Do 537.

57) See id.

58) Cast Away Investigating Records, HankooK Ilbo (Seoul), Sep. 20, 2006.

59) http://www.scourt.go.kr/scourt_en/jdc_info/jdc_reform/index.html (last visited Sep. 15, 2007). 
protocols made by the police and the prosecutors as evidence. I acknowledge that a police officer or a public prosecutor can possibly interrogate persons to find out what really happened but to qualify their findings as evdience in the court is a totally different thing. I insist that the transcripts and protocols cannot be used as evidence without the consents of the defendants and their lawyers. ${ }^{60)}$

Accordingly, the CPC article 312(2) states that "[a] protocol containing interrogation of a suspect prepared by investigation authorities other than a public prosecutor may be used as evidence, only in case where the defendant who has been a suspect, or the defense counsel at a preparatory hearing or during public trial verifies the contents of the protocol."'61) However, the legislator himself showed a more lenient attitude towards the prosecutor's protocol by saying that:

Nonetheless, the human resources in the prosecutorial offices are better than those working in the police stations, so at least for accelerating the trial process, we need to approve the evidentiary power of the protocols that the prosecutors made. ${ }^{62}$

And more than fifty years have passed after the first promulgation of the CPC. In the mean time, the prosecutors' protocols were widely acceted by the trial courts and the courts seemed to be ready to approve the results of the investigation without any scrutinized assessment. Otherwise, the percentage of the guilty in trial could not be so high, as some commentators have pointed out. ${ }^{63)}$

The situation being so, the paradigm shift in 2004 is quite revolutionary to the point of view of the prosecutorial office. The recently amended CPC has made two big changes. ${ }^{64)}$ One is to put off the interrogation of the defendant after all the takings of evidence. ${ }^{65)}$ By doing that, the importance of the prosecutors' protocols of the

60) Dongwoon Shin, Criminal Procedure Code [Hyeongsa sosongbeop] 804, n.3 (3d ed. 2005).

61) CPC, supra note 5, at art. 312(2).

62) DongwoOn SHIN, supra note 60, at 804, n.3.

63) See, e.g., "The percentage of acquittal is fluctuating between $0.4 \%$ and $0.6 \%$," SANGKI PARK et al., CRIMINAL Policy [HyeOngSAJEONGCHAiK] 432 (7d ed. 2003).

64) First of all, the old article 312(1) has been replaced with a new one, which requires that the defendant himself should recognize in an open trial the correctness of the protocol prepared by the prosecutor, see CPC supra note 5, at art. 312(1).

65) CPC, supra note 5, at art. 296-2. 
suspects' statements as evidence has been substantially lowered. The other is to attack the admissibility of the other protocols which are made in the course of interrogating the witnesses, victims, and all the third parties. In consequence, the newly amended article declares that:

A protocol which contains a statement of the person other than the defendant, prepared by a public prosecutor, may be introduced into evidence, on the condition that the statement is subject to cross-examination by the defendant or his lawyer, if it is made under the due process and method, and that the genuineness thereof is proved by the person making the original statement at a preparatory hearing or during public trial, or by objective proof such as videotapes: Provided, that it is proved that the statement was made in specifically trustworthy circumstances. ${ }^{66)}$

All this means that the validity and the legality of the prosecutor's pretrial examination will be fully inspected by the trial court using the exclusionary rule of evidence. The article emphasizes not only "specifically trustworthy circumstances" but also "due process and method." Even though they are guaranteed, what is recorded in the prosecutor's protocol should be "subject to cross-examination." Looking at the wording of the article, we cannot help concluding that the Korean prosecutor is no longer as nearly powerful as the examining magistrate. In a certain sense, the position of the prosecutor can be compared to that of the English JP whose role was closer to the police than to the prosecutors. ${ }^{67)}$ It might be possible that the trial court considers the protocol made by the prosecutor as records that "only have the value of simple information." ${ }^{68)}$

66) CPC, supra note 5, at art. 312(4).

67) Historical research shows that the records made by the JPs have been treated as inconclusive, and their foundational requirements are basically same with the wordings in the article 312(4). See "Sir Matthew Hale's account, bearing the impress of his judicial experience, underscores how exceptionally the depositions of witnesses were used in evidence, and how inconclusive the written examination of the accused might be: These examinations and informations ... may be read in evidence against the prisoner, if the informer be dead, or so sick, that he is not able to travel, and oath thereof made; otherwise not. But then, 1. Oath must be made either by the justice or coroner, that took them, or the clerk that wrote them, that they are the true substance of what the informer gave in upon oath, and what the prisoner confessed upon his examination. 2. As to the examination of the prisoner, it must be testified, that he did it freely without any menace, or undue terror imposed upon him; for I have often known the prisoner disown his confession upon his examination, and hath sometimes been acquitted against such his confession,” JOHN H. LANGBEIN, supra note 6, at 29. 


\section{Conclusion}

The fact that the Korean prosecutor comes to be compared to the English JP means that a transition occurs from the "prosecutorial justice" ${ }^{" 69)}$ to another paradigm. It is visibly clear that the prosecutor is coming down from the place of magistrate to that of a subordinate to the examining magistrate, i.e. district judge.

\section{Conclusion}

I repeat that the prosecutorial neutrality has been at issue in Korea. Certainly, the prosecutorial work has been much distorted. However, the prolem is not in whether the prosecutors are neutral or not. It is more dangerous the fact that he has the power which is not legally given to him. Even if he is not an examining magistrate or district judge, he seems to have the right to "compile an authoritative written dossier recording his examinations of witnesses and accused." ${ }^{\prime 0)}$ But this is not at all desirable. Car there was also not any means to stop the prosecutor's misuse of power.

All the more horribble was that the courts themselves aggravated this problem by abandoning their duty of control. Now, the Judiciary Reform in Korea begins to consider the prosecutor just as the commander of the investigation and, at the same time, as the proper party in an open trial. It means that the true adversarial system will be introduced and tried here. I am curious to see how the prosecutorial office will react in this paradigm shift. Visibily, the prosecutors are well prepared for the change.

However, we also need to remember that the prosecutor is still a member of the magistracy. He is in the control tower and there, he has to do a lot of things. To stop working as the judge, it is also a good thing for the prosecutor himself. He has to now find a way of cooperating with the examining magistrate as one of two key players of the whole criminal procedure.

KEY WORD: prosecution, inquisitorial, justice of the peace, civil-law tradition, interrogation

68) Supra note 51.

69) Kuk Cho, supra note 3, at 386.

70) JoHn H. LANGBEIN, supra note 6, at 33. 